\title{
Three Adaptations of Dracula: Friedrich Murnau, Tod Browning, Francis Ford Coppola, and the Liminal Vampire
}

\begin{abstract}
Of the numerous cinematographic adaptations of Bram Stoker's Dracula (1897), three main cinematographic works - Murnau's Nosferatu (1922), Browning's Dracula (1931) and Coppola's Dracula (1992) - remind us of the true meaning of Bram Stoker's novel and of its decadent origin. Stoker's literary project was to embody artistic representation through the figure of Dracula. The three filmic adaptations make him a liminal figure: they express his position between life and death, between referentiality and representation, through the liminal spaces that the character crosses. Murnau and Coppola, however, stand at opposite ends of the spectrum: one tries to give his work complete autonomy in relation to the original work, while the other purports to go back to the novel and to link it to its historical source. Browning is in an intermediary position as he refers to the theatre adaptation of Dracula as well. Its innumerable retellings transform the story of Dracula into a myth. Adaptation thus becomes both an interpretation of the source and a synthesis of previous transpositions. The three examples examined here have renewed the myth of Dracula, turning the character into an archetype of the crossing of forbidden borders. They illustrate the function of adaptation as an aesthetic and symbolic dislocation from the original and, at the same time, as a return to its original meaning.
\end{abstract}

Keywords: Bram Stoker, Dracula myth, film adaptation, Francis Ford Coppola, Friedrich Murnau, Tod Browning, vampires

The long tradition of cinematographic adaptations of Dracula may lead us to forget its author's original purpose. In 1897, Bram Stoker, as is well known, wanted to write another Picture of Dorian Gray, and Oscar Wilde declared that this new interpretation of the Gothic imagination, a few years after his own work, was the most beautiful novel of the century (Sadoul 1993, 565). Stoker's literary project was to use the Gothic revival to illustrate the aesthetic ideas of the Decadent movement: Dracula, who does not grow old and never dies, embodies the work of art, and he is always, in the novel, the object of a representation built by all the other characters through the many voices mixed together in the narrative. He remains in a position between action and representation, between life and death. 
Among the many adaptations of Dracula, three are particularly intent on using the visual possibilities that film offers to create a figure of liminality. First, Murnau's Nosferatu (1922), whose expressionist aesthetics shaped the subjectivity of the cinematographic image. Second, Browning's Dracula (1931), the first film adaptation of Stoker's novel to be authorized, which even more clearly than Murnau's film represents Dracula's in-between status using spaces of liminality such as doorways and balconies. Third, following several decades of vampire horror movies, Coppola's Dracula (1992) returns to the literary source, as the subtitle After Bram Stoker suggests. Its plot recalls the historical origin of the character, and this splitting of the film between past and present emphasizes the dual and symbolic aspect that is part of the liminality of the Dracula myth, which Stoker linked to a reflection on aesthetic representation.

Stoker's Dracula has to be understood in light of the crisis of representation. The end of the novel can be compared to the end of The Picture of Dorian Gray. In Wilde's novel, Dorian Gray's face at the moment of his death reveals the passage of time since he made his unholy pact and thus remained young. Now he looks so decrepit that he can only be recognized by his rings. Along with the painting, the ring is here an expression of art as opposed to human life. At the end of Bram Stoker's novel, nothing remains of Dracula but dust, which seems to be what should remain of his corpse after the four centuries of his life. But in actual fact, there remains no trace of Dracula's existence, and the entire novel can be read as if the character was only a figment of other characters' imagination - exactly like Dorian Gray, who was more a work of art than a human being. This might be an explanation for the strange form of the story, in which there is not a constant narrator: the narrative is sustained instead by various documents that reflect different voices, whether characters' diaries or letters, or journal articles, bringing different perspectives and subjectivities into the text.

Dracula is the object of a representation. He is the only one whose point of view never enters the story-telling process; he has no direct presence in the text, but instead is seen through the other characters' perceptions. For example, during the sea crossing on his journey to London, the ship's entire crew gradually disappears, and when the captain's log is found, it leads to the supposition that the crew was murdered. All descriptions of Dracula are provided by characters and are only impressions. The portrait of Mina when she becomes a vampire at the end of the novel is similar:

The beautiful colour became livid, the eyes seemed the throw out sparks of hell-fire, the brows were wrinkled as though the folds of the flesh were the coils of Medusa's snakes, and the lovely, blood-stained mouth grew to an open square, as in the passion masks of the Greeks and Japanese. (Stoker 1997, 284-285) 
This impressionistic portrait erases Mina's presence and illustrates the decadent interpretation of Schopenhauer's World as Will and Representation (2014): the world is my representation, and no representation fits the truth of the world. Dracula does not exist in himself, but only as the representation of a subjectivity. This is why he is called "undead": neither dead, nor alive. He does not really belong to the world but is rather a representation of collective fears.

The first film to capture this aspect was Murnau's Nosferatu, which is not actually the first cinematographic adaptation of Dracula: a year earlier, in 1921, Károly Lajthay had already made his own silent film entitled Drakula's Halála [Dracula's Death], of which no copy remains. The story of Murnau's film is well known: Bram Stoker's widow, Florence, did not accept the adaptation, and despite Murnau's changing the settings (the plot takes place in Bremen and not in London) and the names of characters (the vampire is called Count Orlok, for instance), the destruction of the film was ordered in 1925 . Fortunately, a few copies survived. ${ }^{1}$

The reason for this opposition was that Florence Stoker had sold the rights of the novel to Hamilton Deane, an actor who transposed the novel for the stage in 1924, himself playing Van Helsing, with Edmund Blake as Dracula. His success in Dublin encouraged him to perform the play in London, and then, in 1927, in New York, with Bela Lugosi in the role of Dracula. Lugosi was also the main actor of Tod Browning's talkie of 1931.

The three films set out to transpose Stoker's reflections about subjectivity to the screen. Dracula is not a monster in the simple meaning of a frightening creature: he is the embodiment of the uncertain border between imagination and reality, and he is a monster in the sense that he belongs to both these worlds. For example in Browning's film, Lucy feels she is about to change (00:40:00). At that moment, she is becoming a vampire, but at the same time, she is about to marry, so her feeling can have both meanings. A little earlier, when Van Helsing asks her about what could have caused the two marks on her throat, the waitress says "Dracula," but she is in fact introducing the latter, and not answering Van Helsing, which confirms Dracula's dual position.

This play on ambiguities points to Dracula's metaphysical position. In Coppola's film, Dracula answers Mina's question about his nature by saying that he is nothing (1:37:32). One interpretation of art that enlightens Stoker's, Murnau's, Browning's, and Coppola's aesthetic purpose is the notion of a being "between two deaths" which was developed by Jacques Lacan in his Ethics of Psychoanalysis. Lacan (1997, 315-333) proposes an analysis of Antigone, whose artistic beauty,

1 Subsequent rereleases of the film undid some of the changes, for example Werner Herzog's 1979 remake. 
according to him, is situated between two deaths, giving her character its sparkle. Like Antigone, Mina in Browning's film is presented as glamorous when she is between two deaths, about to become a vampire (1:01:00).

This position between two deaths is explained in several passages of Stoker's novel by Van Helsing: as mentioned earlier, Dracula is "undead," meaning that he is neither dead nor alive, and that he belongs to both worlds at the same time. In the films, this position takes the visual form of tension between materiality and immateriality. In Browning's film, the immateriality of the vampire is shown when Harker meets him: at first, Harker does not see him, but then he follows him and remarks that he crosses spiders webs without tearing them (0:11:00). In this scene, the crossing of thresholds is linked to the immateriality of the vampire. A most famous example of this incorporeal presence is Murnau's calèche scene, which translates Stoker's own insistence on the alteration of all perceptions:

The time seemed interminable as we swept on our way, now in almost complete darkness, for the rolling clouds obscured the moon. We kept on ascending, with occasional periods of quick descent, but in the main always ascending. (Stoker 1997, 20)

Murnau undertakes to give a visual form to this hypnotic impression: he uses a disjointed movement with curves, and the music adds to the hypnotic impression. Coppola aims to produce the same impression, albeit differently: he returns to Stoker's text, which focuses on the two black horses leading the carriage, and makes their arrival seem to take place in a kind of levitation.

However, the scene in Coppola's film which probably shows best the immateriality of the vampire is the one with Jonathan and the three female vampires. The scene may be an allusion to Goethe's ballad "Die Braut von Korinth" ["The Bride of Corinth"] (1797), the very first literary text on vampires, in which a female vampire figure enters a young man's room. But, in Coppola's film, it is mainly the representation of a pure fantasy; the woman emerges from nowhere between the legs of the man lying on the floor. At the beginning of the scene, the arrival of the vampire is shown by traces of her presence, but there is no discernible body. And then, when the female vampire (played by Monica Bellucci) does appear, her very sensuality strengthens the contrast between the corporality and immateriality of the vampire.

In these examples, the three movies seek to interpret the meaning of the vampire in Stoker's novel. Linda Hutcheon, in her Theory of Adaptation, explains that adaptation is not a simple copy: "The adapted text, therefore, is not something to be reproduced, but rather something to be interpreted and recreated, often in a new medium" (2006, 84). From these two functions, interpretation and recreation, two aspects of adaptation emerge: adaptation transposes into another 
medium and gives explanations. For example, nobody understands where the madman Renfield comes from in Stoker's novel, how he became mad, and why he is connected with Dracula. In Murnau's film, Renfield becomes the one who sends Jonathan Harker to Dracula's castle. In Browning's film, Renfield (and not Harker) goes to Dracula's castle and becomes mad, and the two Harkers stay in London, since there is no Carpathian pursuit in this film.

Coppola takes up Murnau's idea, but he remains close to Stoker's novel. For example, Dracula tells Harker that he is the last one of his kind. The sentence in question is taken from Stoker's novel, where it refers to a decadent character who, like des Esseintes in Huysmans's A rebours, is the last in his line: he is a character who does or creates nothing, being art himself. In the same way, Dracula does nothing but what he is told to do in Stoker's novel. The Demeter episode, which Stoker invented on the basis of the real wreck of the Dimitry of Narva in Whitby harbour in 1885, is ambiguous: the murders of the crew are the object of no narration, so the episode can be read as if the whole crew had died from disease. When Van Helsing recounts Dracula's medieval past, taking the position of the writer, he places Dracula in the context of pure fiction. The same ambiguity applies to Jonathan's letters, where Dracula is the object of his imagination. In each case, Dracula appears as the embodiment of fiction.

Coppola is also the only one of the three directors to use the episode of the baby who is killed by the three female vampires. This brutal episode was taken from one of the two books written against the historical character of Dracula in the fifteenth century, the Story of Prince Dracula, probably by Ulrich Han and published in Vienna in 1463. This book relates all the cruelties of the Prince, and is probably a propaganda book commissioned by the King of Hungary in order to weaken prince Dracula. In Coppola's film, he is called Vlad after his historical name, Vlad the Impaler, famous for impaling his enemies on forests of stakes; and indeed, the very beginning of the film refers to the 1463 battle against the Turks and shows the impaling in a symbolic scene in black and red, thus upholding the link between the historical and the fictional Draculas.

Indeed, if Coppola adapts Stoker, he also brings the story back to its historical sources, and he also adapts the adaptors - Murnau and Browning. As in Browning's film, Coppola's Dracula drinks no wine but speaks of the soft music of the wolves, which he calls the “children of the night." When Dracula enters Lucy's room, he appears as a shadow destroying the flowers, which is a double allusion to Murnau and Browning (0:58:30). Adaptation also takes the form of synthesis, and Coppola enlightens his adaptation by using other sources: he claims to have been inspired by Cocteau's La Belle et la Bête [Beauty and the Beast] (1946), for example in the scene where Jonathan sees Dracula crawling on the walls of his castle. This movement is also present in Stoker's novel, but the style of crawling, 
with sliding lateral movements, is indeed taken from Cocteau. The scene of Lucy's rape, when Dracula has taken the form of a beast and does not want to be seen by Mina, is also inspired by Beauty and the Beast. ${ }^{2}$

Coppola's borrowings from Browning and Murnau are numerous. The play on colours also refers to Browning's movie. Mina explains to Dr Seward that Dracula appeared to her with two red eyes and a white face. This opposition between red and white is used in another way by Coppola, who creates an opposition between Lucy, in red, and Mina, in white. Through the allusion to Browning, Coppola gives Dracula, who is both red and white, an intermediate position between Lucy, who is dead, and Mina, who is alive. In Browning's movie, when Mina joins Dracula, she is in a white dress and he is in black (0:46:00). He is beyond the doorway and makes her cross it. The opposition of colours here enlightens the opposition of characters and spaces: the door represents a limit between two worlds, between life and death.

In the three films, Dracula is shown as the one who crosses limits; he is the character of thresholds, always shown crossing doorways or windows, because he belongs to two worlds and constantly goes from one to the other. In Browning's film, after having crossed a barrier of spiders' webs without tearing them (0:11:00), Dracula is in the doorway to save Jonathan from being killed by the three female vampires (0:17:30); this image is built on the opposition between inside, where the three women stand, dressed in white, in front of Jonathan, who is lying on the floor, and outside, where Dracula appears in black. Here, the liminal space is represented by a contrast between the two sides of the border, which is strengthened by the opposition of colours, underlining the symbolic meaning. The doorway symbolizes here the limit between life and death, embodied both by Dracula and Jonathan lying on the floor. In Murnau's film, the closed door cannot protect Harker (0:23:00). Dracula not only crosses the physical barrier of the door, but also the spiritual limit between souls, as he affects Mina through Jonathan (0:23:00).

More generally, telepathy in the three films contributes to this liminal function. In Browning's film, telepathy is linked to passing through a window (0:37:00): first Dracula is in telepathic contact with Renfield, then he enters Mina's room. He is therefore a character who crosses both physical and immaterial limits and also crosses the borders between materiality and immateriality. One possible interpretation of this structure is that the function of this character is to question both the nature of the world (Dracula would be a monstrous embodiment of the theory of

2 Dracula's figure at this moment looks like the Beast. More precisely, the scene of Lucy's rape seems to be a counterpart of the scene in Beauty and the Beast where the Beast is next to Belle's bed. It also reminds us of the scene where Belle falls asleep in the Beast's arms in the forest. 
Baudelaire's correspondences) and of human beings: Dracula's telepathic position is that of the alter ego, and telepathy works as a mirror of the spirit, a message addressed by the spirit to itself.

In the three films, as in the novel, the mirror is a space of transition. One of the literary topoi attached to monsters is the lack of reflection in a mirror. For example, the eponymous character in Maupassant's Horla (1886) faces an empty mirror. After Stoker's novel, Walter de la Mare used the topos again in 1899 in The Return, as did Edouard Schuré in Le Double in 1910. Donald Winnicott offers his interpretation of this motif when he describes a mother's eyes as the mirror of a newborn child: "What does the baby see when he or she looks at the mother's face? I am suggesting that, ordinarily, what the baby sees is himself or herself" $(2005,151)$. Dracula represents the eyes of the mother and he offers the characters around him a reflection. This is why he has no reflection of his own. In Browning's film, this function of the mirror is obvious: the characters are referred to themselves; seen in a mirror, they seem to speak alone (0:42:00).

Coppola's film transforms Stoker's view: Dracula is not only the object of representation, but is the gaze itself, and as such he refers to an in-between space. When Harker is about to go to the Carpathians and leave Mina behind, the plants around them are like eyes that observe them. This gaze facilitates the passage from one reality to another, as the image of the plant transforms itself into that of a tunnel (0:08:00). The Carpathian space then turns nature into another image of this gaze (0:08:55): through the letter which translates Dracula's voice in this extract, mysterious eyes looking at Harker are signs of a presence at the crossing point of two worlds.

All of Dracula's story is about the opposition between two worlds. Stoker's novel has often been interpreted as showing the opposition between the past, represented by the Carpathian world, and the present, represented by Victorian London. Monstrosity, which is literally the combination of two heterogeneous beings, is here to be found in the manifestation of the past in the present; it is the crossing of forbidden borders, such as the border between life and death. In the three films, transitional images underline the chasm between two worlds. Such liminal spaces take different forms, such as, for example, a street in Murnau's film (0:54:00) where, after Dracula has introduced the plague, corpses build a line separating the dark and the sunny sides of the street - and the window, from which the street is seen, is another separation between interior and exterior spaces. In the same way, the very beginning of Browning's film shows two mountains separated by a path through which the calèche, carrying Renfield, passes on its way to Dracula's castle.

This structure in two symmetrical parts illustrates the very nature of the vampire, who can be a reflection, a double, or a shadow. Coppola uses it too, but 
with a slight difference. Mina, talking with Dracula, evokes the Carpathian environment which she has seen in her previous life (1:06:00). The scene's background is shared between two spaces: on the left-hand side, the castle, and on the righthand side, the restaurant in London where they find themselves, representing respectively the past and the present. When she evokes the princess of Dracula's story, the two parts become three (1:06:00). Dracula's in-between space is therefore not only situated between two realities, but occasionally between three. When Harker goes to the Carpathians and looks at a map, he notices that this space is between Transylvania, Moldova, and Bucovina; so that the organization of the fiction into a double space, London and the Carpathians, turns into a triple one.

In Browning's film, Dracula takes with him to London three boxes of his country's soil; this number has a strong symbolic meaning, for the two sides (life and death) of Dracula's hybrid nature turn here into a triple nature, evoking another trinity. The same thing occurs in another image relating Dracula to Mina. After Lucy's death, Mina and Jonathan marry, which creates a symmetry (1:06:42). This symmetry is represented by the two staircases of the church, one going down in white, the other going up in red. There are three windows in each staircase. This complex play on the symbolic value of numbers is a way to slide from one meaning of the vampire to another. The number two refers to Dracula's nature, situated between life and death: Dracula is the one who, coming back from death, reproduces Christ's experience in a blasphemous way. The number three refers to the triple nature of God. Dracula, representing a trinity of a different kind, thus challenges God, so that the vampire can be interpreted as a modern Promethean or Faustian myth.

Coppola strengthens both the outline of the story and its symmetries. For example, two babies are given to female vampires in the course of the film: Dracula gives a baby to three vampires at the beginning, and, after her death, Lucy brings a little girl back to her tomb. In this way, the motif of the baby eaten by vampires is used as one of the plot's frames. The whole structure of the film is also framed by a double and symmetrical vertical movement: Elisabeta dies at the beginning, and there is an ascension towards God at Dracula's death (2:01:00) at the end. The vertical movement, which gives its meaning to the whole story, linking it to a relationship between the vampire and God, builds another frame within the fiction. After having liberated her lover from vampire life, Mina looks at the portrait of the two lovers painted on the ceiling. The whole film is structured by two kinds of movement: horizontal movements with the various trips between London and the Carpathians, which seem to represent the quest; and vertical ones, with Elisabeta's fall at the beginning, which is repeated by Jonathan's fall from Dracula's castle, and the final ascension. These vertical movements seem to suggest the achievement of the quest. 
Such symmetries and, more generally, the structure of the double foreground the act of artistic representation. In Browning's film, a policeman goes to the cemetery, where he finds a lady dressed in white, Lucy. The image of him in front of the gate of the cemetery and about to enter it (0:49:00) is a clear allusion to Caspar David Friedrich's painting of 1825, Entry into the Cemetery. Browning's entire film also alludes to the music of the second act of Tchaikovsky's Swan Lake, which creates a counterpart to the plot, and Dracula's first appearance takes place during an opera. In Coppola's film, the representation is linked to cinema. The scene where Dracula seduces Mina takes place at a film exhibition (0:52:14). The structure is symmetrical and, once again, this symmetry presents three images: one showing Dracula and Mina; an image on the screen with a naked woman, which can be understood as a figuration of Mina's desire; and the wolf, who seems to represent Dracula. Thus, the references to cinema and painting, doubling the plots with symbolic images, turn whole scenes into dramatizations of artistic representations, and the films themselves become reflections on that process.

The idea of representation itself is expressed through references to multiple arts: in Murnau through architecture (the shape of the castle is an allusion to the Gothic novel), in Browning through music and painting, and in Coppola through cinema. But the films also refer to literature, and not only to Stoker. Murnau's plot is grounded in the Book of Vampires, ${ }^{3}$ Browning's is focused on the Arabian Nights in Burton's translation (1885), ${ }^{4}$ and Coppola retains a quotation in Stoker from Bürger's "Lenore": "Denn die Todten reiten schnell” ["For the dead travel fast"] (Stoker 1997, 13; my translation). ${ }^{5}$ In the ballad in question, the young lady watches the empty horse of her lover coming back from the Battle of Prague and does not want to accept his death. When she follows the horse, she discovers a living dead man. In the three films, the Gothic reference is made clear by play on the form of the castle. However, Coppola gives the castle an almost human appearance, which suggests an identification with Dracula (0:11:45, 0:56:55). Could the identification of Dracula with his castle be understood as an allusion to Poe's "Fall of the House

3 Dudley Wright's Book of Vampires was first published in 1914. A second revised edition appeared in 1924, two years after Nosferatu. Wright's Vampires and Vampirism: Collected Stories from around the World was also published in 1914.

4 Bram Stoker met Burton in the Company of the Beefstacks dining club. Burton had gathered Indian tales in a work entitled Vikram and the Vampire, or Tales of Hindu Devilry (Burton 1893), first published in 1870.

5 This is an approximate quotation from Gottfried August Bürger's ballad "Lenore” (1773), in which a woman waits for the return of her fiancé Wilhelm after the Seven Years War. She accompanies on horseback the mysterious young man who had knocked at her door at midnight, and, when she asks why he rides so quickly, the stranger answers: "die Todten reiten schnell” (Bürger n.d.). 
of Usher” (1839), in which Usher is identified with his house? An adaptation is a work made from another or by alluding to another, and these relationships in the three adaptations take the form of a correspondence between the arts. This relationship attaches more firmly the myth of Dracula to its decadent origin. The idea of the correspondence appears in the subtitle of Murnau's film: Eine Symphonie des Grauens [A Symphony of Horror]. The vertical correspondence, in the Baudelairean sense, is used by Coppola when Dracula describes his lover, Elisabeta: the princess's face is a river, she is a flower, a river of tears, sadness, and despair. Both the concrete and abstract meanings of the word "river" are combined here, creating a link between the physical and moral worlds. Besides, the princess and the river that killed her are connected, so that Elisabeta appears as a new Ophelia, drowned in a river in her love. Ophelia's figure is attached to Hamlet, but has become a literary myth at least since Rimbaud's poem (1870) and creates a link not only between literary genres (tragedy and lyrical poetry), but also between the arts: the topos has an important place in particular in the works of Delacroix, Millais, or Waterhouse, and now finds an illustration in cinema through Coppola's work. Thus, the analogy between Elisabeta and Ophelia not only denotes the relationship between cinema and literature, but also the unity between all the arts, while introducing a mythification of the story.

The mythical reference constitutes the final structural network of allusions that the three adaptations have in common. In Murnau's version, Jonathan's decision to go to the Carpathians looks like a pact with the devil when Jonathan and Renfield shake hands at the beginning (0:05:00). In Browning's film, the meeting of all the doctors talking about Dracula reminds us of the central place of knowledge according to Faust (0:31:52): in this image, the light over the table and the books on the shelves represent rational and scientific knowledge, but the masks and the outside space of the mountain seem to be linked to the magic and forbidden knowledge that Faust wanted to gain.

Claude Lévi-Strauss $(1958,242)$ states that all the versions of a myth belong to the myth and are part of its history and its meaning. Through the allusions to the myths of Faust and Ophelia, and by applying the notion of correspondences between the arts, Murnau, Browning, and Coppola together propose a particular approach to adaptation. For them, adaptation produces a new work, a new creation which is at the same time an interpretation of the source and a synthesis of previous interpretations. And this idea of a synthesis which is also a transformation, leads to the project of creating a new Dracula myth: our three films interpret Dracula as a myth of liminality, where the challenge to God takes the form of the crossing of the metaphysical borders between life and death, and the crossing of the aesthetical borders between referentiality and representation. 


\section{Works cited}

La Belle et la Bête. Dir. Jean Cocteau. Distina, 1946.

Bürger, Gottfried August. “Lenore.” 1773. Songs of Darkness. Mark Andrew Holmes, n.d. http:// markandrewholmes.com/lenore.html (20 May 2018).

Burton, Richard Francis. A Plain and Literal Translation of the Arabian Nights' Entertainments, Now Entituled [sic] The Book of the Thousand Nights and a Night. Benares: Kamashastra Society for Private Subscribers Only, 1885.

Burton, Richard Francis. King Vikram and the Vampire, or Tales of Hindu Devilry. 1870. London: Tylston and Edwards, 1893.

Dracula. Dir. Tod Browning. Universal Pictures, 1931.

Dracula: After Bram Stoker. Dir. Francis Ford Coppola. Columbia Pictures, 1992.

Hutcheon, Linda. A Theory of Adaptation. New York and London: Routledge, 2006.

Huysmans, Joris-Karl. Against Nature. 1884. Trans. Patrick McGuinness. London: Penguin Classics, 2003.

Lacan, Jacques. Seminar of Jacques Lacan: The Ethics of Psychoanalysis: Book VII. Trans. Dennis Porter. 1986. New York: Norton, 1997.

Lévi-Strauss, Claude. Anthropologie structurale. Paris: Plon, 1958.

Nosferatu, eine Symphonie des Grauens. Dir. Friedrich Wilhelm Murnau. Pranea Film, 1922.

Nosferatu: Phantom der Nacht. Dir. Werner Herzog. Werner Herzog Filmproduktion-Gaumont-ZDF, 1979.

Sadoul, Barbara. “Notice biographique.” Dracula. By Bram Stoker. Trans. Lucienne Molitor. Paris: J'ai lu, 1993.

Schopenhauer, Arthur. The World as Will and Representation. Vol. 1. 1818. Ed. and trans. Judith Norman, Alistair Welchman, and Christopher Janaway. Cambridge: Cambridge University Press, 2014.

Stoker, Bram. Dracula. 1897. Ed. Nina Auerbach and David J. Skal. New York and London: Norton, 1997.

Winnicott, Donald. Playing and Reality. 1971. London and New York: Routledge Classics, 2005. Wright, Dudley. The Book of Vampires. 1914. Minneola and New York: Dover, 1924.

Wright, Dudley. Vampires and Vampirism: Collected Stories from around the World. 1914. Washington: Westphalia Press, 2017.

Bernard Franco is a professor of General and Comparative Literature at Sorbonne University. He is the current president of the European Society of Comparative Literature. His research mainly focuses on European Romanticism (especially drama), on French-German cultural transfers, and on the relationships between literature and aesthetics. He is the author of La Littérature comparée: Histoire, domaines, méthodes (Paris: Armand Colin, 2016). 
